\title{
rRNA operons and genome size of 'Candidatus Liberibacter americanus', a bacterium associated with citrus huanglongbing in Brazil
}

\author{
Correspondence \\ S. Eveillard \\ Sandrine.Eveillard@ \\ bordeaux.inra.fr
}

\author{
N. A. Wulff, ${ }^{1}$ S. Eveillard, ${ }^{2}$ X. Foissac, ${ }^{2}$ A. J. Ayres ${ }^{1}$ and J.-M. Bové ${ }^{2}$ \\ ${ }^{1}$ Fundecitrus - Fundo de Defesa da Citricultura, Araraquara, SP, CEP 14807-040, Brazil \\ ${ }^{2}$ Université de Bordeaux 2 and INRA UMR 1090, 33883 Villenave d'Ornon, BP 81, France
}

\section{INTRODUCTION}

Huanglongbing (HLB) is one of the worst diseases of citrus and endangers the very existence of citriculture (Bové, 2006). Known in China since the 1870s and South Africa since 1928, HLB emerged in 2004, 2005 and 2006, respectively, in São Paulo state (Brazil), Florida (USA) and Cuba (Bové, 2006; Llauger et al., 2008). Three 'Candidatus Liberibacter' species are associated with HLB. In Africa, only 'Candidatus Liberibacter africanus' (Laf) has been detected and, in Asia, 'Candidatus Liberibacter asiaticus' (Las) has been the only species to be found (Jagoueix et al., 1994, 1997; Bové, 2006). São Paulo state harbours, in addition to Las (Coletta-Filho et al., 2004; Teixeira et al., 2005a), a third liberibacter species, 'Candidatus Liberibacter americanus' (Lam) (Teixeira et al., 2005a, b, c). Citrus trees in Florida and Cuba may be infected only with Las. Liberibacters are not available in axenic culture. They are phloem sieve tube-restricted members of a novel subgroup of the Alphaproteobacteria, with members of the alpha-2 subgroup as their closest relatives (Jagoueix et al., 1994, 1997). Two psyllid insect vectors, in which the liberibacters circulate and multiply,

Abbreviations: HLB, huanglongbing; Laf, 'Candidatus Liberibacter africanus'; Lam, 'Candidatus Liberibacter americanus'; Las, 'Candidatus Liberibacter asiaticus'.

The GenBank/EMBL/DDBJ accession numbers for the $r r s$ and $r r / / r r f$ gene sequences of Lam isolate São Paulo are FJ036892 and FJ036893, respectively. are responsible for the rapid spread of liberibacters between citrus species, as well as citrus relatives such as Murraya paniculata (jasmine orange) (Lopes et al., 2005). The African citrus psyllid Trioza erytreae transmits Laf in Africa, while the Asian citrus psyllid Diaphorina citri vectors Las and/or Lam in Asia and the Americas (Bové, 2006; Yamamoto et al., 2006). Each of the three liberibacters can be transmitted by dodder (Cuscuta campestris) to periwinkle plants (Catharanthus roseus), in which they reach higher titres than in citrus and induce severe symptoms (Garnier \& Bové, 1983; Teixeira et al., 2008a).

Because the liberibacters have not been available in culture, infected periwinkle plants have been one of the major experimental sources of liberibacters. However, as it is difficult to get liberibacter DNA that is uncontaminated with plant DNA, only a few liberibacter genes have been characterized, as follows: the genes for the rRNA $(\mathrm{rrn})$ operon, the rplKAJL-rpoBC gene cluster or $\beta$-operon and a few additional genes ( $n u s G$, pgm, omp, hypothetical protein gene) isolated by the RAPD method (Hocquellet et al., 1999). The $16 \mathrm{~S}$ rRNA gene and the 16S-23S intergenic region were obtained by PCR amplification with universal primers for prokaryotic rRNA genes, using DNA from liberibacter-infected periwinkle plants as target DNA (Jagoueix et al., 1994, 1997). The rRNA gene region has recently been extended (Lin et al., 2008). Part of the $\beta$ operon was obtained in the early 1990s as a $2.6 \mathrm{kbp}$ DNA 
fragment (In-2.6) by random cloning of DNA from periwinkle plants infected with the Poona (India) strain of Las (Villechanoux et al., 1993). Next, DNA from periwinkle plants infected with the South African Nelspruit strain of Laf was amplified with a primer pair designed from In-2.6 and yielded, after cloning and sequencing, a $1.7 \mathrm{kbp}$ DNA fragment (AS-1.7) of the $\beta$-operon of Laf (Planet et al., 1995). Comparison of the sequences of In-2.6 and AS-1.7 confirmed that the Asian and African liberibacters represented two distinct species (Planet et al., 1995). When, in 2005, the third liberibacter species, Lam, was described (Teixeira et al., 2005a, b, c), its $\beta$-operon was not available. The $\beta$-operon of the American liberibacter, as well as three upstream genes ( $t u f B, \sec E$ and $n u s G)$, have now been obtained by the technique of chromosome walking and characterized (Teixeira et al., 2008a). Furthermore, the $\beta$-operon sequence of Laf, only partially known previously, was completed, making it possible to compare the $\beta$-operon sequences of African, Asian and American liberibacter strains over a length of $\sim 3000 \mathrm{bp}$ (Teixeira et al., 2008a). The $\beta$-operon gene cluster of Las, as well as the omp locus (Hocquellet et al., 1999; Bastianel et al., 2005), have recently been extended by an improved genomic walking technique (Lin et al., 2008).

Evidence for the presence of more than one $r r n$ operon in liberibacters was discovered while comparing the 16S-23S intergenic regions of Las and Laf (Jagoueix et al., 1997). Here, we show that Lam probably has three rrn operons on a circular genome, the size of which is $1.29-1.34 \mathrm{Mbp}$, based on data from PFGE and hybridization assays. The sequences of the $23 \mathrm{~S}$ and $5 \mathrm{~S}$ rRNA genes of Lam have also been obtained.

\section{METHODS}

Plant material and DNA extraction. Seedlings of periwinkle (Catharanthus roseus 'Peppermint Cooler') were grown in the Bordeaux laboratory greenhouse at $\sim 25{ }^{\circ} \mathrm{C}$ during the day and $\sim 20{ }^{\circ} \mathrm{C}$ at night. The initial periwinkle plant infected with Lam was obtained by dodder transmission from a symptomatic sweet orange seedling that had been graft-inoculated with the São Paulo strain of Lam. To generate large numbers of Lam-infected periwinkle plants, pieces of shoot from the initial symptomatic periwinkle plant were top-grafted onto healthy periwinkle seedlings. The plants were used when they showed generalized symptoms. Symptomatic periwinkle leaves infected with Lam were used as the source material for DNA extraction and the preparation of high-molecular-mass liberibacter DNA. Uninfected periwinkle leaves were used as controls. Whenever symptomatic leaves were used, they were always checked by PCR to confirm infection with Lam (Teixeira et al., 2005b).

DNA preparations from symptomless, uninoculated periwinkle plants and symptomatic plants infected with Lam were obtained from leaf midribs by the CTAB procedure (Murray \& Thompson, 1980). The DNA preparations were treated with RNase A and proteins were removed by phenol treatment before quantification of DNA from UV absorption at $260 \mathrm{~nm}$.

Amplifying, cloning and sequencing of ribosomal genes. The sequences of the 16S rRNA gene (rrs) (GenBank accession number
AY859542.1) and the 16S-23S intergenic region (AY742824.1) of Lam were from Teixeira et al. (2005c).

The DNA upstream of rrs was obtained by PCR amplification with degenerate forward primer rrs_UpDeg (5'-AGAAAGRGARACGTGGRCGGC), based on consensus sequences upstream of the $16 \mathrm{~S}$ rRNA gene from selected rhizobia (see below), and reverse primer GB3 (Teixeira et al., 2005b) (Fig. 1). PCR was carried out in a $50 \mu \mathrm{l}$ reaction mixture containing $200 \mathrm{ng}$ DNA, $1 \times$ PCR buffer (Invitrogen), $2.0 \mathrm{mM} \mathrm{MgCl} 2,0.2 \mathrm{mM}$ of each dNTP, $500 \mathrm{nM}$ of each primer and 1.5 U Taq DNA polymerase. PCR conditions were as follows: initial denaturation at $95{ }^{\circ} \mathrm{C}$ for 2 min, 35 cycles of $92{ }^{\circ} \mathrm{C}$ for $30 \mathrm{~s}, 67{ }^{\circ} \mathrm{C}$ for $30 \mathrm{~s}$ and $72{ }^{\circ} \mathrm{C}$ for $90 \mathrm{~s}$ and a final extension of $72{ }^{\circ} \mathrm{C}$ for $4 \mathrm{~min}$. The amplicon from Lam-infected periwinkle DNA was cloned into the pGEMT-Easy vector (Promega). One microlitre of the ligation mixture was then used to transform competent Escherichia coli DH10B by electroporation (Bio-Rad). The cloned DNA was sequenced using Genome Express facilities (http://www.gexbyweb. com/gexbyweb) with T7 promoter primer and SP6 primer.

The $r r l$ gene, together with the $r r f$ gene, was obtained by PCR amplification with forward primer GB4 (5'-TTACCGACGTTAGATAACCGGACG), designed from the 16S-23S intergenic region (Teixeira et al., 2005c), and reverse primer GB11 (5'-CTACCGGGCTGCTCCACCCC), designed to anneal at the RNA $^{\text {Met }}$ sequence located at the end of the rrn operon. The sequence of GB11 was based on the consensus sequences downstream of $r r f$ from selected rhizobia (see below). PCR was carried out as described above, except that the annealing temperature was $64^{\circ} \mathrm{C}$. E. coli transformation and sequencing were as described, except that the following primers were also used for sequencing: GB5 (5'-GCTACCTTAGGACCGTTATAGTTACG), GB6 (5'-GTAACTATAACGGTCCTAAGGTAGCG), GB9 (5'-CTTTAAGCAGGAACCCTTGG) and GB13 (5'-GGCTGGATGTGGAAGCTGGGTA) (Fig. 1).

Sequence analysis. Sequences of the $r r s, r r l$ and $r r f$ genes and $1 \mathrm{kbp}$ sequences upstream and downstream of the $r r n$ genes were retrieved from the NCBI Complete Microbial Genomes database (http:// www.ncbi.nlm.nih.gov/genomes/MICROBES/microbial_taxtree.html) for the following strains: Agrobacterium tumefaciens C58 (GI:159185562), Rhizobium leguminosarum bv. viciae 3841 (GI:116249766), Sinorhizobium meliloti 1021 (GI:15963753), Brucella melitensis $16 \mathrm{M}^{\mathrm{T}} \quad(\mathrm{GI}: 17988344)$, Bartonella henselae Houston- $\mathrm{1}^{\mathrm{T}}$ (GI:49474831), Nitrobacter winogradskyi Nb-255 (GI:75674199) and Bradyrhizobium japonicum USDA 110 (GI:27375111). The sequence of the 16S rRNA gene and part of the 23S rRNA gene from Las isolate GuangXi-GL-1 (GenBank accession no. DQ778016; Lin et al., 2008) was also selected. Multiple sequence alignments were performed using CLUSTAL W software (Thompson et al., 1994). Searches for identities between sequences were carried out using the BLAST algorithm (Altschul et al., 1997). tRNA searches were conducted with tRNAscan-RE (Lowe \& Eddy, 1997).

Sequences obtained from cloned PCR fragments were trimmed to remove plasmid sequences and amplification primers and consensus sequences were generated from multiple overlapping sequences with CodonCode Aligner (CodonCodeCorporation).

\section{Preparation of DNA probes}

Probe for ribosomal protein genes. A DNA fragment of $878 \mathrm{bp}$ encompassing rplA and rplJ of Lam was PCR-amplified in the presence of DIG-11-dUTP (Roche) as described previously (Teixeira et al., 2008a), yielding probe rplAJ.

Probes for rRNA genes. An rrs amplicon was obtained with universal bacterial primers fD1/rD1 (Weisburg et al., 1991) from a DNA preparation of Lam-infected periwinkle leaves (Teixeira et al., 2005b) 


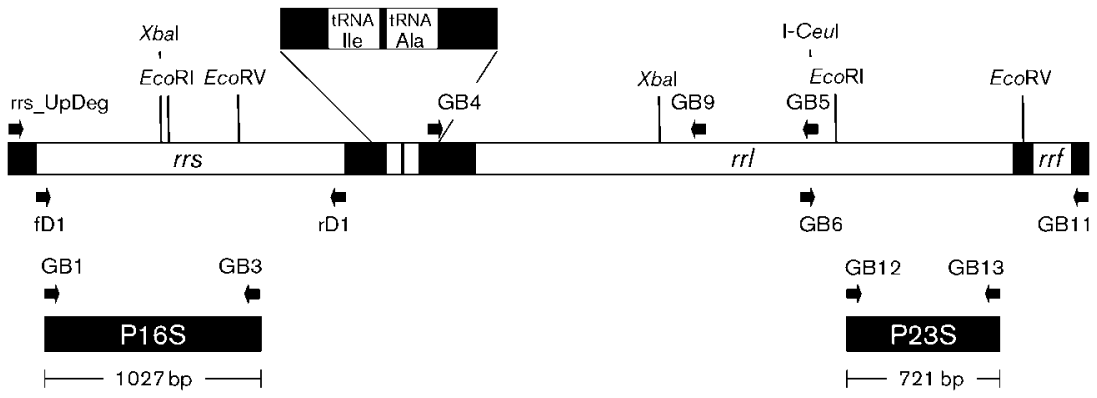

Fig. 1. Schematic representation of the $r r n$ operon in Lam. rrs, 16S rRNA gene; rrl, $23 S$ rRNA gene; rrf, 5S rRNA gene. The 16S-23S intergenic spacer region contains tRNA genes for lle and Ala. Positions of restriction sites are indicated by vertical lines. The positions of primers on the rrn operon are given by arrows. Sequences corresponding to probes P16S and P23S are depicted.

and used as template in a second PCR with primers GB1 and GB3 in the presence of DIG-11-dUTP (Roche), yielding an rrs probe of 1027 bp named P16S (Fig. 1).

Probe P23S (721 bp) was generated by amplification with forward primer GB12 (5'-GGTAGGCATTGAAGCAGAGGCG) and reverse primer GB13 (5'-GGCTGGATGTGGAAGCTGGGTA) in the presence of DIG-11-dUTP (Roche), in a nested reaction with the $23 \mathrm{~S}$ rRNA gene as template (see above) (Fig. 1).

Preparation of Lam genomic DNA High-molecular-mass genomic DNA was prepared as described previously (Neimark \& Kirkpatrick, 1993; Padovan et al., 2000) with minor modifications. Briefly, $1.5 \mathrm{~g}$ periwinkle leaf midrib was ground in $5 \mathrm{ml}$ ice-cold extraction buffer $\left[100 \mathrm{mM} \mathrm{Na} \mathrm{HPO}_{4}, 30 \mathrm{mM} \mathrm{NaH} \mathrm{PO}_{4}\right.$, pH 7.2, $2 \%$ PVP 40000 , $10 \mathrm{mM}$ EDTA, pH 8.0, 0.15\% BSA, $1 \mathrm{mM}$ isoascorbic acid, $10 \%$ sucrose and $1 \%$ macerozyme (Yakult)], using a Homex model 6 homogenizer (Bioreba). The resulting suspension from multiple samples was transferred into centrifuge tubes $(6 \times 29 \mathrm{ml})$, incubated for $1 \mathrm{~h}$ in a water bath at $30{ }^{\circ} \mathrm{C}$ with occasional gentle stirring and centrifuged at $1500 \mathrm{~g}$ for $5 \mathrm{~min}$ and the supernatant was filtered through two layers of cheesecloth. Centrifugation and filtration were repeated. The filtered, low-speed supernatants were pooled and centrifuged at $18000 \mathrm{~g}$ for $30 \mathrm{~min}$ at $4{ }^{\circ} \mathrm{C}$. The resulting green pellet was gently resuspended in $20 \mathrm{ml}$ suspension buffer $(20 \mathrm{mM}$ Tris/ $\mathrm{HCl}$, $50 \mathrm{mM}$ EDTA, pH 8.0, $10 \%$ sucrose). The suspension was again centrifuged at $1500 \mathrm{~g}$ for $5 \mathrm{~min}$, filtered and centrifuged at $18000 \mathrm{~g}$. Each pellet was resuspended in $150 \mu$ l suspension buffer; the pellets were pooled and centrifuged at $18000 \mathrm{~g}$. The final pellet was gently resuspended in $150 \mu \mathrm{l}$ suspension buffer, brought to $40{ }^{\circ} \mathrm{C}$ for $3 \mathrm{~min}$ and mixed with an equal volume of $2 \%$ molten, low-melting-point agarose (Bio-Rad) dissolved in $2 \times$ TSE $(0.2 \mathrm{M}$ Tris/ $\mathrm{HCl}, 20 \mathrm{mM}$ EDTA, pH 8.0, $0.2 \mathrm{M} \mathrm{NaCl}$ ) maintained at $50{ }^{\circ} \mathrm{C}$. The agarose suspension was moulded into blocks by pipetting $80 \mu \mathrm{l}$ of the suspension into plastic moulds and allowed to set at $4{ }^{\circ} \mathrm{C}$ for $15 \mathrm{~min}$. Agarose blocks were expelled into lysozyme buffer $(10 \mathrm{mM}$ Tris/ $\mathrm{HCl}$, $\mathrm{pH}$ 7.5, $50 \mathrm{mM} \mathrm{NaCl}, 100 \mathrm{mM}$ EDTA, $0.5 \%$ sarcosine). Lysozyme was freshly added to a final concentration of $1 \mathrm{mg} \mathrm{ml}^{-1}$, and the blocks were left in the lysozyme solution for $36 \mathrm{~h}$ at $37^{\circ} \mathrm{C}$, replacing the lysozyme solution with fresh solution every $12 \mathrm{~h}$. The last lysozyme solution was replaced with lysis buffer (100 mM EDTA, $0.5 \%$ SDS). Proteinase (Roche) was added to a final concentration of $1 \mathrm{mg} \mathrm{ml}^{-1}$ and left at $50{ }^{\circ} \mathrm{C}$ for 5 days, the proteinase solution being replaced every $12 \mathrm{~h}$. At the end of the proteinase treatment, blocks were washed three times with TE $(10 \mathrm{mM}$ Tris/HCl, $1 \mathrm{mM}$ EDTA, $\mathrm{pH}$ 8.0) and twice with $1 \mathrm{mM}$ PMSF in TE buffer to inactivate the proteinase. The blocks were stored at $4{ }^{\circ} \mathrm{C}$ in $20 \mathrm{mM} \mathrm{Tris} / \mathrm{HCl}$, $50 \mathrm{mM}$ EDTA ( $\mathrm{pH} 8.0)$ before treatment with or without restriction endonucleases and used for PFGE.

Restriction endonuclease digestion and PFGE. Agarose blocks were incubated for $1 \mathrm{~h}$ in $1 \times$ restriction enzyme buffer supplied with the enzyme, and digested in $80 \mu \mathrm{l}$ enzyme buffer containing BSA (final concentration $100 \mu \mathrm{g} \mathrm{ml}^{-1}$ ) and $50 \mathrm{U}$ enzyme at the recommended temperature for $18 \mathrm{~h}$. Enzymes used were SmaI, BamHI, I-CeuI, ApaI, SacII, SalI, NotI, PauI, SfiI, SmiI and PmeI.

PFGE was performed by the contour-clamped homogeneous electric field technique using the CHEF-DR III system (Bio-Rad) with $1 \%$ PFGE agarose (Bio-Rad). Electrophoresis was performed at $6 \mathrm{~V} \mathrm{~cm}^{-1}$ at an included angle of $120^{\circ}$ in $0.5 \times$ TBE buffer $(45 \mathrm{mM}$ Tris/borate, $1 \mathrm{mM}$ EDTA; Bio-Rad) maintained at $14{ }^{\circ} \mathrm{C}$ with varying ramped pulse times. Pulse conditions were selected according to the size ranges of the DNA fragments under study. Molecular masses were estimated by comparisons with a lambda ladder (catalogue no. N0340S; New England Biolabs) and chromosome standards of Saccharomyces cerevisiae and Hansenula wingei (Bio-Rad catalogue numbers $170-3605$ and 170-3667).

For resolution of low-molecular-mass DNA fragments $(<30 \mathrm{kbp})$, DNA prepared by the CTAB protocol was used in large amounts (150 $\mu \mathrm{g}$ per lane). Restriction endonucleases EcoRI, XbaI, EcoRV and $B g l$ II were used according to the manufacturer's instructions (New England Biolabs and Promega) and electrophoresis was performed in the CHEF-DR III system.

Southern hybridization. For Southern hybridization, PFGE gels were stained with ethidium bromide followed by extensive destaining before image capture under UV light, using FluorS with software QuantityOne (Bio-Rad). A long destaining period was critical for optimal visualization of digested fragments. Gels were treated for three successive 15 min periods in solution $\mathrm{A}(0.25 \mathrm{M} \mathrm{HCl})$ and then in solution $\mathrm{B}(0.5 \mathrm{M} \mathrm{NaOH}, 1.5 \mathrm{M} \mathrm{NaCl})$ and finally in solution $\mathrm{C}$ (0.25 M Tris/HCl, pH 7.5, $1.5 \mathrm{M} \mathrm{NaCl})$. Gels were blotted overnight onto nylon membranes (NitranSuperCharge; Schleicher \& Schuell) in $10 \times$ SSC. The membranes were washed in $2 \times$ SSC for $5 \mathrm{~min}$ and the DNA was fixed by baking the membranes at $80{ }^{\circ} \mathrm{C}$ for $2 \mathrm{~h}$ (Charles \& Ishikawa, 1999). Pre-hybridization and hybridization were performed at $42{ }^{\circ} \mathrm{C}$. Four low-stringency washings were carried out for $15 \mathrm{~min}$ each in $2 \times$ SSC containing $0.5 \%$ SDS at room temperature, followed by two washings for $30 \mathrm{~min}$ each in $0.1 \times$ SSC containing $0.1 \%$ SDS at $65{ }^{\circ} \mathrm{C}$. Detection of DIG-labelled probes was done according to the manufacturer's recommendations (Roche).

\section{RESULTS AND DISCUSSION}

\section{Sequences of Lam $r r l$ and $r r f$}

Sequence alignments from $r r n$ regions of selected genomes were used to design primers in highly conserved regions. Downstream of rrs there are three highly conserved regions: (i) an I-CeuI site, located in the $r r l$ gene (Liu et al., 1993); (ii) the $r r f$ gene, with high sequence identity to that in species of the Rhizobiales and (iii) a 78 bp stretch 
overlapping the tRNA ${ }^{\mathrm{Met}}$ region. Primer GB11, designed to this region, and primer GB4, designed to the $r r s / r r l$ intergenic region, were used to amplify $r r l$ and $r r f$ and the $r r l / r r f$ intergenic region as a $3142 \mathrm{bp}$ fragment that was cloned and sequenced. Upstream of $r r s$, a conserved DNA stretch of 21 nucleotides was identified and used to design degenerate primer rrs_UpDeg. Using primer rrs_UpDeg in combination with primer GB3, the $5^{\prime}$ part of rrs and the upstream DNA were amplified. The amplified DNA spanned the fD1 recognition site (Weisburg et al., 1991) up to the rrs_UpDeg-binding site, adding $158 \mathrm{bp}$ to the previous rrs sequence (Teixeira et al., 2005c).

Based on the results above, the $r r l$ and $r r f$ genes span 2803 and $119 \mathrm{bp}$, respectively, and they are separated by a $41 \mathrm{bp}$ intergenic region that contains no tRNAs. The $r r l$ gene from Lam had the highest sequence identity ( $95 \%)$ to the $r r l$ gene from Las strain Sihui (GenBank accession no. EU644449), followed by the sequences of Shinella zoogloeoides ATCC $19623^{\mathrm{T}}$ (X88894) and A. tumefaciens C58 (AE007870.2), both with $89 \%$ identity. The $r r f$ gene from Lam again had the highest sequence identity (95\%) to the $r r f$ gene from Las strain Sihui (GenBank accession no. EU644449), while the rrf genes from both Sinorhizobium meliloti 1021 (AL591688) and Sinorhizobium medicae WSM419 (CP000738) shared $88 \%$ identity with the Lam sequence. All these bacteria belong to the Rhizobiaceae.

The complete rrs gene from Lam strain São Paulo (this work and Teixeira et al., 2005c) has 1495 bp and the closest match (95\% sequence identity) is the complete rrs sequence from Las strain GuangXi-GL-1 (GenBank accession no. DQ778016.1), followed by (i) the partial rrs sequences from liberibacters associated with members of the Solanaceae, 'Ca. Liberibacter' sp. NZ082226 (EU834130.1) and 'Ca. Liberibacter psyllaurous' Tx15 (EU812556.1), and Laf (L22533), with $94 \%$ sequence identity, and (ii) the complete sequences from $R$. leguminosarum 3841 (AM236080) and Rhizobium etli CFN $42^{\mathrm{T}}$ (CP000133.1), with $90 \%$ identity. The sequence of the $r r s / r r l$ intergenic region is also known (Teixeira et al., 2005c). In total, the Lam $r r n$ represents a stretch of 5187 bp between primers rrs_UpDeg and GB11 (Fig. 1).

\section{Analysis of Lam DNA by PFGE and Southern hybridization: estimation of genome size}

After mild homogenization of midribs from Lam-infected periwinkle leaves, preparations enriched in liberibacter cells were obtained by alternating low- and high-speed centrifugations. The final pellet was resuspended and immobilized in agarose blocks before DNA extraction by lysozyme and proteinase treatments. Similar blocks were obtained from midribs of uninoculated periwinkle plants. Carrying out the treatments for DNA preparation on material embedded in agarose blocks is thought to minimize mechanical shearing of DNA strands. In the experiments shown in Fig. 2, the blocks were submitted to PFGE without any restriction endonuclease treatment, and the gels were stained with ethidium bromide. PFGE has been used widely to obtain high-molecular-mass DNA from non-cultured bacteria such as phytoplasmas and to determine the size of their genomes (Marcone et al., 1999). In the PFGE gels (Fig. 2a, b), a faint band (arrows) is present in lanes containing DNA from plants infected with the liberibacter (lanes L), but not in lanes containing DNA from uninfected plants (lanes PW). We conclude that this band represents liberibacter DNA for the following reasons. (i) It can be stained with ethidium bromide. (ii) After transfer of the gel shown in Fig. 2(b) to a nylon membrane and Southern hybridization with probe rplAJ, specific to Lam, a hybridization signal was observed in lane L, but not in lane PW of Fig. 2(c), and the position of the signal corresponded very precisely to the position of the band on the PFGE gel of Fig. 2(b). (iii) As indicated above, in the results shown in Fig. 2(a, b), the DNA blocks were not treated with restriction endonuclease prior to PFGE. However, when such treatments were applied, in particular with endonucleases such as I-CeuI and SalI, which cut liberibacter genomic DNA, no bands were observed in the lanes $\mathrm{L}$ and, after transfer to a nylon membrane and Southern analysis, no hybridization signal was detected in the region corresponding to the signal in Fig. 2(c) (data not shown).

From comparisons with DNA size markers, the DNA band in Fig. 2 had an estimated size of 1.29 Mbp. In addition to the hybridization signal given by the $1290 \mathrm{kbp}$ DNA band, (a)

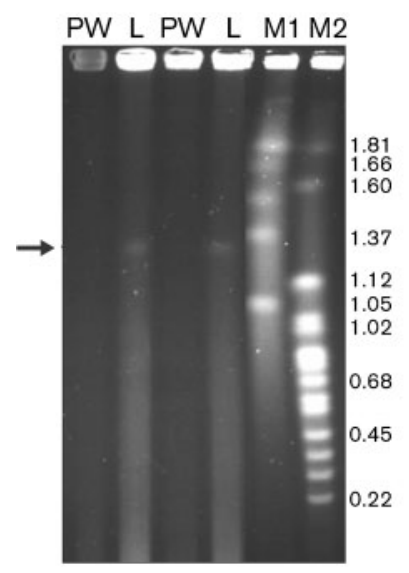

(b)

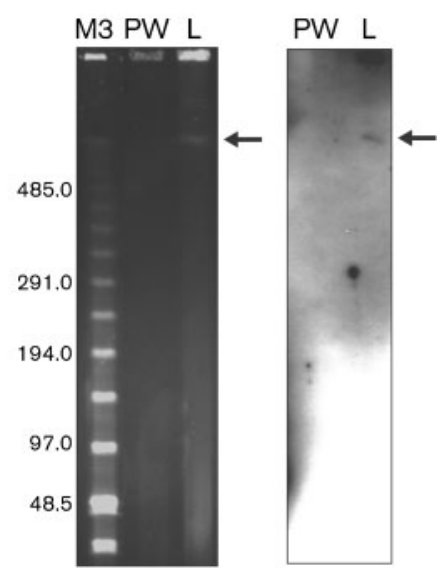

Fig. 2. PFGE of chromosomal DNA of Lam isolate São Paulo. (a, b) Ethidium bromide-stained gels of undigested PFGE of chromosomal DNA from healthy periwinkle plants (PW) and plants infected with Lam (L). PFGE parameters were $1-12 \mathrm{~s}$ for $6 \mathrm{~h}$ and $60-120 \mathrm{~s}$ for $16 \mathrm{~h} \mathrm{(a)} \mathrm{or} 2-40 \mathrm{~s}$ for $19 \mathrm{~h} \mathrm{(b)} \mathrm{at} 6 \mathrm{~V} \mathrm{~cm}^{-1}$. (c) Southern blot hybridization of membrane from the gel shown in (b) with probe rplAJ. Arrows point to chromosomal DNA of Lam. DNA size markers (kbp) are as follows: M1, DNA from Hansenula wingei; M2, DNA from Saccharomyces cerevisiae; M3, $\lambda$ DNA ladder. 
Fig. 2(c) shows a rather strong hybridization signal in the well of lane L, indicating that an appreciable amount of liberibacter DNA did not move out of the well during PFGE. As circular genomic DNA does not migrate as effectively as linearized DNA (Marcone et al., 1999; Neimark \& Kirkpatrick, 1993), some of the DNA in the well might correspond to the circular form of genomic DNA, and the 1.29 Mbp DNA band to the linearized form. In general, the DNA blocks are submitted to gamma irradiation before PFGE in order to introduce single, random cuts into the circular double-stranded DNA genome molecules and increase the number of linearized genomes moving into the PFGE gel. In the experiments reported here, gamma irradiation was not used, and this may explain why the band of linearized genomic DNA was faint. As expected, there was no hybridization band in the PW lanes or in the PW well.

Next, the DNA in the agarose blocks from liberibacterinfected leaves and from uninfected leaves was submitted to restriction enzyme treatments (Fig. 3). The I-CeuI endonuclease seemed particularly interesting to use, since the unique location of its restriction site is within the $\mathrm{rrl}$ gene of most bacteria (Liu et al., 1993), and the enzyme is frequently used to determine the number of $r r n$ operons during PFGE mapping. In Lam, the I-CeuI site is towards the $3^{\prime}$ end of the $r r l$ gene (Fig. 1). In experiments with endonucleases, the DNA to be digested is not only the putative linearized DNA of $1.29 \mathrm{Mbp}$, but also the more abundant, putative circular undigested DNA remaining in the well during PFGE experiments such as those of Fig. 2(b, c). Under these conditions, digestion with I-CeuI resulted in three bands of high-molecular-mass DNA (C1, C2 and C3, in descending order of mass) when blocks with DNA from liberibacter-infected leaf midribs were used (Fig. 3; PFGE gel, I-CeuI, lane L), but no bands were seen with the blocks with DNA from uninfected control leaves (Fig. 3;
PFGE gel, I-CeuI, lane PW). Probe P16S hybridized with $\mathrm{C} 1$ and $\mathrm{C} 3$ (Fig. 3; P16S, I-CeuI, lane L) and probe P23S hybridized with C2 and C3 (Fig. 3; P23S, I-CeuI, lane L). Based on the DNA markers, the mean \pm SD sizes of fragments C1, C2 and C3 generated upon digestion with I-CeuI, estimated from three independent experiments, were found to be respectively $494 \pm 4,447.7 \pm 3$ and $399.7 \pm 3 \mathrm{kbp}$. The sum of the sizes of fragments $\mathrm{C} 1, \mathrm{C} 2$ and C3 amounted to $1.341 \mathrm{Mbp}$, a value close to that of 1.29 Mbp found for the DNA band of Fig. 2. The size of the Lam genome would thus be in the range 1.29-1.34 Mbp.

Of the restriction enzymes used, ApaI, NotI, PauI, SfiI and PmeI did not cut the Lam genomic DNA. I-CeuI cut the chromosome in three fragments (Fig. 3). Restriction enzymes SmaI, BamHI, SacII, SalI and SmiI gave different restriction patterns (not shown).

A genome size in the range of 1.29-1.34 Mbp places Lam in the lower range of genome sizes among alphaproteobacteria, with Neorickettsia sennetsu Miyayama ${ }^{\mathrm{T}}$ (GenBank accession no. NC_007798) having the smallest sequenced alphaproteobacterial genome, namely $859 \mathrm{kbp}$. Of all bacteria capable of self-replication in artificial media, the mollicute Mycoplasma genitalium G-37 ${ }^{\mathrm{T}}$ (GenBank accession no. NC_000908) has the smallest genome, at $580 \mathrm{kbp}$. Although the liberibacters have not yet been cultured axenically in vitro, the genome of Lam appears to be about twice as large as that of the culturable $M$. genitalium. Phytoplasmas also belong to the class Mollicutes and, like the liberibacters, are (i) associated with plant diseases, (ii) restricted to the plant sieve tubes in the phloem, (iii) have sieve tube-feeding insects as vectors and (iv) are not available in culture. Their known genome sizes vary from $530 \mathrm{kbp}$ for the bermudagrass white leaf phytoplasma to $1350 \mathrm{kbp}$ for the stolbur phytoplasma (Marcone et al., 1999). As pointed out previously (Marcone et al., 1999;

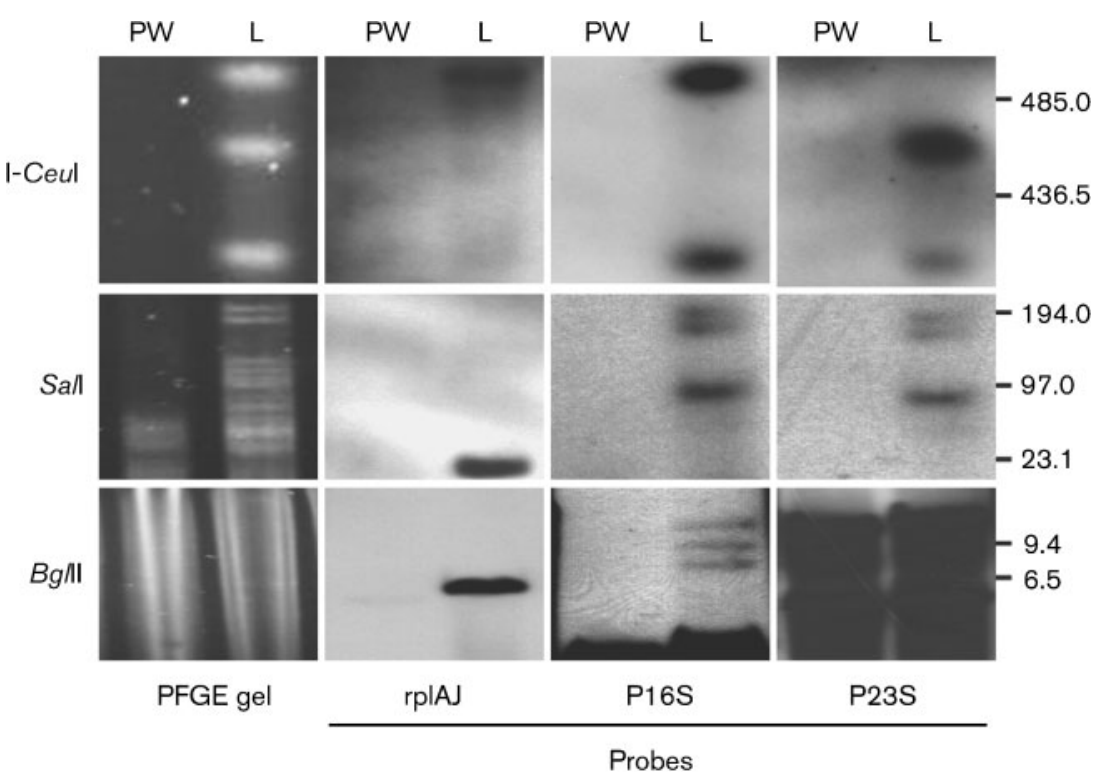

Fig. 3. PFGE of DNA of Lam isolate São Paulo and hybridization with probes rplAJ, P16S and P23S after Southern blot. Plugs containing chromosomal DNA of healthy periwinkle (PW) or Lam-infected periwinkle (L) digested with I-Ceul or Sall were electrophoresed at $2-40 \mathrm{~s}$ for $40 \mathrm{~h}, 6 \mathrm{~V} \mathrm{~cm}^{-1}$ at $120^{\circ}$ included angle (l-Ceul) or $1-12 \mathrm{~s}$ for $4 \mathrm{~h}$ and $60-120 \mathrm{~s}$ for $16 \mathrm{~h}$ at $6 \mathrm{~V} \mathrm{~cm}^{-1}$ (Sall). DNA of healthy periwinkle (PW) or Lam-infected periwinkle (L) digested with $\mathrm{Bg} / \mathrm{ll}$ was electrophoresed at $0.5-12 \mathrm{~s}$ for $12 \mathrm{~h}, 6 \mathrm{~V} \mathrm{~cm}^{-1}$. DNA size markers (kbp) are Saccharomyces cerevisiae DNA and a $\lambda$ DNA ladder. 
Neimark \& Kirkpatrick, 1993), the genome sizes of many phytoplasmas are larger than those of many culturable human and animal mycoplasmas and, therefore, small genome size alone does not explain the fact that phytoplasmas or liberibacters have not yet been obtained in axenic culture.

\section{Number of rrn operons on a circular liberibacter genome}

As I-CeuI cuts only within the rrl gene (Liu et al., 1993) and I-CeuI digestion of the liberibacter genome yields three DNA fragments ( $\mathrm{C} 1, \mathrm{C} 2$ and $\mathrm{C} 3)$, the genome is either circular with three ribosomal $\mathrm{rrn}$ operons or linear with two ribosomal rrn operons. The following results suggest that the genome is circular with three rrn operons.

After digestion with I-CeuI, the hybridization signal with probe rplAJ showed that the rplKAJL-rpoB operon is located in the $\mathrm{C} 1$ fragment (Fig. 3). Probe P16S, binding to an extended portion of the rrs gene, hybridized with fragments $\mathrm{C} 1$ and $\mathrm{C} 3$, and the hybridization signal with $\mathrm{C} 1$ was stronger than with $\mathrm{C} 3$ (Fig. 3), suggesting that $\mathrm{C} 1$ carries two rrs genes and C3 only one. Probe P23S, binding to the $3^{\prime}$ portion of the $r r l$ gene, hybridized with $\mathrm{C} 2$ and C3, the hybridization signal with $\mathrm{C} 2$ being stronger than with $\mathrm{C} 3$, suggesting that $\mathrm{C} 2$ carries two $r r l$ genes. Bands $\mathrm{C} 1$, $\mathrm{C} 2$ and $\mathrm{C} 3$ were obtained reproducibly, with the hybridization signals to $\mathrm{C} 1$ and $\mathrm{C} 2$ being stronger than that of $\mathrm{C} 3$ in independent experiments. However, in some Southern blot experiments, high-molecular-mass DNA not cut with restriction enzymes failed to be detected, probably because of small amounts of liberibacter DNA in the infected leaves, especially in the winter months when growing conditions for plants were less favourable than at other times of the year.

After genomic DNA digestion with SalI, hybridization with probe P23S revealed three bands with sizes of 199, 181 and $110 \mathrm{kbp}$. The two larger bands were close together but clearly distinct (Fig. 3). The same hybridization pattern was obtained with probe P16S, even though the two upper bands were less distinct. Interestingly, the known sequences of the Lam rrn operon have no Sall site (this work and Teixeira et al., 2005c). However, SalI digestion does produce restriction fragments (Fig. 3; PFGE gel, Sall, L), and these fragments must result from restriction sites located between the $r r n$ operons. The fact that the same three fragments hybridized with P16S and P23S is further evidence for the occurrence of three rrn operons in Lam.

Additional data concerning the number of rrn operons were obtained after digestion with frequently cutting enzymes. In this case, restriction enzyme treatments were carried out on DNA in solution, without immobilization in blocks. Digestion with BglII and hybridization with probe P16S resulted in three hybridizing bands with DNA from liberibacter-infected periwinkle only (Fig. 3; P16S, L). Hybridization with probe $\mathrm{P} 23 \mathrm{~S}$ was hindered by plant
DNA and could not be evaluated (Fig. 3; P23S, PW and L). As there are no BglII sites in the sequences of the known Lam rrn operon (this work and Teixeira et al., 2005c), the BglII sites must be downstream and upstream of each $\mathrm{rrn}$ operon, accounting for three hybridization signals with probe P16S and further supporting the occurrence of three rrn operons in Lam.

Digestion of genomic DNA with I-CeuI produces three fragments (C1, C2 and C3) and the results of Southern blot hybridizations with probes $\mathrm{P} 16 \mathrm{~S}$ and $\mathrm{P} 23 \mathrm{~S}$ are consistent with the presence of three rrn operons (Fig. 3). A genome with three $r r n$ operons and three DNA fragments upon digestion with I-CeuI should have a circular configuration. If the genome is linear with three $r r n$ operons, four DNA fragments would be generated upon digestion with I-CeuI. A linear genome generating three DNA fragments upon I$\mathrm{CeuI}$ digestion should have only two rrn operons. Hybridization with probes P16S and P23S for fragments C1, C2 and C3 accounts for a circular genome with three rrn operons, and not for a linear genome with two or four rrn operons. Besides, Southern hybridization results indicate that two rrn operons are in the same orientation and the third is in the opposite orientation (Fig. 4): (i) fragment $\mathrm{C} 1$ displayed hybridization only for P16S, which indicates that the two $r r n$ operons located at the ends of $\mathrm{C} 1$ $(r r n A$ and $r r n B)$ are in opposite orientations; (ii) fragment C2 hybridized only with P23S, which also indicates that it harbours two rrn operons in opposite orientations; and (iii) as C3 had hybridization signals with both P16S and P23S, it must harbour two rrn operons in the same orientation. Fig. 4 summarizes the position and orientation of Lam rrn operons based on our hybridization results.

Among bacterial genomes, the number of $r r n$ operons varies considerably, from one to 15 (Klappenbach et al., 2000; Charles \& Ishikawa, 1999). In E. coli K-12, the

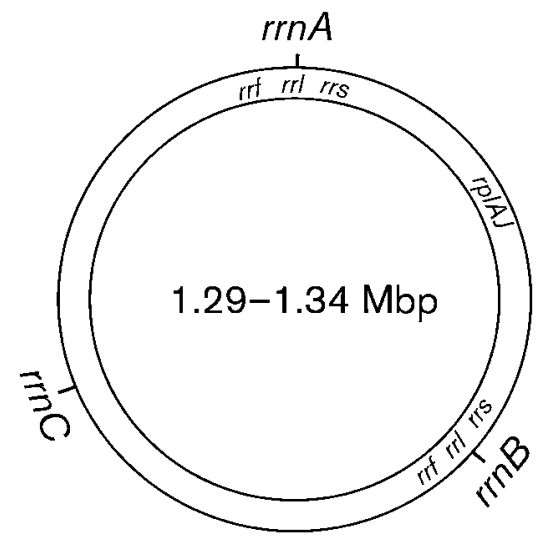

Fig. 4. Ribosomal operon location in the Lam genome. Locus $r p / A J$ is between the $r r n A$ and $r r n B$ operons (fragment $\mathrm{C} 1$ of $445 \mathrm{kbp}$ ), with $r r n A$ orientated anticlockwise and $r r n B$ clockwise. Genome size is derived from PFGE data. Tick marks indicate ICeul restriction sites. 
number of $r r n$ operons was estimated to be seven by restriction endonuclease digestion and hybridization assays (Kiss et al., 1977). In alphaproteobacteria, the rrn copy number is between one and five (Klappenbach et al., 2000). We present evidence for three rrn operons in the Lam genome; the rrn operon number in the other liberibacter species is unknown, although previously our group had indicated that liberibacters harbour at least two 16S rRNA genes (Jagoueix et al., 1997; Garnier et al., 2000).

Finally, probe rplAJ hybridized to a single BglII restriction fragment (Fig. 3; rplAJ, BglII, L). Similar results were obtained with EcoRI, XbaI and EcoRV (not shown). These data suggest that the $r p l K A J L-r p o B$ or $\beta$-operon is present in Lam as a single copy, as in all other proteobacteria, and is well-suited for real-time, quantitative PCR (Teixeira et al., 2008b).

\section{ACKNOWLEDGEMENTS}

The authors would like to thank Patrick Bonnet for periwinkle grafting and greenhouse maintenance, Anelise G. Mariano for technical assistance in cloning, Patricia Carle, Géraldine Gourgues and Sylvie Malembic-Maher for helpful suggestions for PFGE assays and Diva do C. Teixeira for reading the manuscript.

\section{REFERENCES}

Altschul, S. F., Madden, T. L., Schäffer, A. A., Zhang, J., Zhang, Z., Miller, W. \& Lipman, D. J. (1997). Gapped BLAST and PSI-BLAST: a new generation of protein database search programs. Nucleic Acids Res 25, 3389-3402.

Bastianel, C., Garnier-Semancik, M., Renaudin, J., Bové, J. M. \& Eveillard, S. (2005). Diversity of "Candidatus Liberibacter asiaticus," based on the omp gene sequence. Appl Environ Microbiol 71, 64736478.

Bové, J. M. (2006). Huanglongbing: a destructive, newly-emerging, century-old disease of citrus. J Plant Pathol 88, 7-37.

Charles, H. \& Ishikawa, H. (1999). Physical and genetic map of the genome of Buchnera, the primary endosymbiont of the pea aphid Acyrthosiphon pisum. J Mol Evol 48, 142-150.

Coletta-Filho, H. D., Targon, M. L. P. N., Takita, M. A., De Negri, J. D., Pompeu, J., Jr, Machado, M. A., Amaral, A. M. \& Muller, G. W. (2004). First report of the causal agent of Huanglongbing ("Candidatus Liberibacter asiaticus") in Brazil. Plant Dis 88, 1382.

Garnier, M. \& Bové, J. M. (1983). Transmission of the organism associated with citrus greening disease from sweet orange Citrus sinensis cultivar Madame-vinous to periwinkle vinca rosa by dodder (Cuscuta campestris). Phytopathology 73, 1358-1363.

Garnier, M., Jagoueix-Eveillard, S., Cronje, P. R., Le Roux, H. F. \& Bové, J. M. (2000). Genomic characterization of a liberibacter present in an ornamental rutaceous tree, Calodendrum capense, in the Western Cape province of South Africa. Proposal of 'Candidatus Liberibacter africanus subsp. capensis' Int J Syst Evol Microbiol 50, 2119-2125.

Hocquellet, A., Toorawa, P., Bové, J. M. \& Garnier, M. (1999). Detection and identification of the two Candidatus Liberobacter species associated with citrus huanglongbing by PCR amplification of ribosomal protein genes of the $\beta$ operon. Mol Cell Probes 13, $373-379$.
Jagoueix, S., Bové, J.-M. \& Garnier, M. (1994). The phloem-limited bacterium of greening disease of citrus is a member of the $\alpha$ subdivision of the Proteobacteria. Int J Syst Bacteriol 44, 379-386.

Jagoueix, S., Bové, J. M. \& Garnier, M. (1997). Comparison of the $16 \mathrm{~S} / 23 \mathrm{~S}$ ribosomal intergenic regions of "Candidatus Liberobacter asiaticum" and "Candidatus Liberobacter africanum", the two species associated with citrus huanglongbing (greening) disease. Int J Syst Bacteriol 47, 224-227.

Kiss, A., Sain, B. \& Venetianer, P. (1977). The number of rRNA genes in Escherichia coli. FEBS Lett 79, 77-79.

Klappenbach, J. A., Dunbar, J. M. \& Schmidt, T. S. (2000). rRNA operon copy number reflects ecological strategies of bacteria. Appl Environ Microbiol 66, 1328-1333.

Lin, H., Doddapanemi, H., Bai, X., Yao, J., Zhao, X. \& Civerolo, E. L. (2008). Acquisition of uncharacterized sequences from Candidatus Liberibacter, an unculturable bacterium, using an improved genomic walking method. Mol Cell Probes 22, 30-37.

Liu, S.-L., Hessel, A. \& Sanderson, K. E. (1993). Genomic mapping with I-CeuI, an intron-encoded endonuclease specific for genes for ribosomal RNA, in Salmonella spp., Escherichia coli, and other bacteria. Proc Natl Acad Sci U S A 90, 6874-6878.

Llauger, R., Luis, M., Collazo, C., Teixeira, D. C., Martins, E. C., Pena, I., López, D., Batista, L., Prieto, D. \& other authors (2008). PCR detection of Candidatus Liberibacter asiaticus associated with citrus huanglongbing in Cuba. Trop Plant Pathol 33, S93.

Lopes, S. A., Martins, E. C. \& Frare, G. F. (2005). Detecção de Candidatus Liberibacter americanus em Murraya paniculata. Summa Phytopathol 31, 48-49 (in Portuguese).

Lowe, T. M. \& Eddy, S. R. (1997). tRNAscan-RE: a program for improved detection of transfer RNA genes in genomic sequence. Nucleic Acids Res 25, 955-964.

Marcone, C., Neimark, H., Ragozzino, A., Lauer, U. \& Seemuller, E. (1999). Chromosome sizes of phytoplasmas composing major phylogenetic groups and subgroups. Phytopathology 89, 805-810.

Murray, M. G. \& Thompson, W. F. (1980). Rapid isolation of high molecular weight plant DNA. Nucleic Acids Res 8, 4321-4325.

Neimark, H. \& Kirkpatrick, B. C. (1993). Isolation and characterization of full length choromosomes from non-culturable plantpathogenic mycoplasma-like organisms. Mol Microbiol 7, 21-28.

Padovan, A. C., Firrao, G., Schneider, B. \& Gibb, K. S. (2000). Chromosome mapping of the sweet potato little leaf phytoplasma reveals genome heterogeneity within the phytoplasmas. Microbiology 146, 893-902.

Planet, P., Jagoueix, S., Bové, J. M. \& Garnier, M. (1995). Detection and characterization of the African citrus greening Liberobacter by amplification, cloning and sequencing of the $r p / \mathrm{KAJL}-r p o \mathrm{BC}$ operon. Curr Microbiol 30, 137-141.

Teixeira, D. C., Ayres, A. J., Kitajima, E. W., Tanaka, F. A. O., Danet, J. L., Jagoueix-Eveillard, S., Saillard, C. \& Bové, J. M. (2005a). First report of a huanglongbing-like disease of citrus in Sao Paulo State, Brazil, and association of a new liberibacter species, Candidatus Liberibacter americanus, with the disease. Plant Dis 89, 107.

Teixeira, D. C., Danet, J. L., Eveillard, S., Martins, E. C., Jesus Junior, W. C., Yamamoto, P. T., Lopes, S. A., Bassanezi, R. B., Ayres, A. J. \& other authors (2005b). Citrus huanglongbing in São Paulo state, Brazil: PCR detection of the 'Candidatus' Liberibacter species associated with the disease. Mol Cell Probes 19, 173-179.

Teixeira, D. C., Saillard, C., Eveillard, S., Danet, J. L., da Costa, P. I., Ayres, A. J. \& Bové, J. (2005c). 'Candidatus Liberibacter americanus', associated with citrus huanglongbing (greening disease) in São Paulo State, Brazil. Int J Syst Evol Microbiol 55, 1857-1862. 
Teixeira, D. C., Eveillard, S., Sirand-Pugnet, P., Wulff, N. A., Saillard, C., Ayres, A. J. \& Bové, J. M. (2008a). The tufB-secE-nusG-rplKAJL-rpoB gene cluster of the liberibacters: sequence comparisons, phylogeny and speciation. Int J Syst Evol Microbiol 58, 1414-1421.

Teixeira, D. C., Saillard, C., Couture, C., Martins, E., Wulff, N. A., Yamamoto, P. T., Eveillard-Jagoueix, S., Ayres, A. J. \& Bové, J. M. (2008b). Candidatus Liberibacter americanus, agent of huanglongbing disease of citrus in Sao Paulo State, Brazil: distribution and quantification of the liberibacter in leaves of an affected sweet orange tree as determined by PCR methods. Mol Cell Probes 22, 139-150.

Thompson, J. D., Higgins, D. G. \& Gibson, T. J. (1994). CLUSTAL W: improving the sensitivity of progressive multiple sequence alignment through sequence weighting, position-specific gap penalties and weight matrix choice. Nucleic Acids Res 22, 4673-4680.
Villechanoux, S., Garnier, M., Laigret, F., Renaudin, J. \& Bove, J. M. (1993). The genome of the non-cultured, bacterial-like organism associated with citrus greening disease contains the nusG-rplKAJLrpoBC gene cluster and the gene for a bacteriophage type DNA polymerase. Curr Microbiol 26, 161-166.

Weisburg, W. G., Barns, S. M., Pelletier, D. A. \& Lane, D. J. (1991). $16 \mathrm{~S}$ ribosomal DNA amplification for phylogenetic study. J Bacteriol 173, 697-703.

Yamamoto, P. T., Felippe, M. R., Garbim, L. F., Coelho, J. H. C., Ximenes, N. L., Martins, E. C., Leite, A. P. R., Sousa, M. C., Abrahão, D. P. \& Braz, J. D. (2006). Diaphorina citri (Kuwayama) (Hemiptera: Psyllidae): vector of the bacterium Candidatus Liberibacter americanus. In Proceedings of the Huanglongbing-Greening: International Workshop, Ribeirão Preto, SP, Brazil, 16-20 July 2006, p. 18. 